\title{
Research Updates
}

\author{
Helen K. Kim ${ }^{1}$
}

Received: 8 December 2021 / Accepted: 19 December 2021 / Published online: 7 February 2022

(c) The Author(s), under exclusive licence to Springer Nature B.V. 2022

\section{Research from Academic Institutes}

\section{Steinhardt Social Research Institute, Cohen Center for Modern Jewish Studies at Brandeis University}

\section{Institute Reports}

Aronson, J.K., Brookner, M.A., Saxe L. (2021). 2020 Metropolitan Chicago Jewish Population Study. Waltham, MA: Cohen Center for Modern Jewish Studies, Brandeis University.

Aronson, J.K., Brookner, M.A., Saxe L. (2021). 2020 Greater Metrowest NJ Jewish Community Study. Waltham, MA: Cohen Center for Modern Jewish Studies, Brandeis University.

Wright, G., Volodarsky, S., Hecht, S., \& Saxe, L. (2021). Online or On-campus: Learning from the COVID-19 Pandemic. Waltham, MA: Cohen Center for Modern Jewish Studies, Brandeis University.

\section{Research from Non-Academic Institutes}

UJA COVID-19 Impact Study (2021). New York: UJA Federation New York. https://jewishdatany.ujafedny.org/.

Helen K. Kim

kimh2@whitman.edu

1 Whitman College, Walla Walla, WA 99362, USA 


\section{Research from Individual Scholars}

Gold, S.J. (2021). "The Jewish Israeli Diaspora," in The Oxford Handbook of the Jewish Diaspora. Hasia R. Diner (ed)., New York and Oxford, Oxford Handbooks, Oxford University Press.

Belzer, T., Brundage, T., Calvetti, V., Kelman, A.Y., \& Perez, D. (2021). "Beyond the Count: Perspectives and Lived Experiences of Jews of Color." Commissioned by the Jews of Color Initiative. https://www.bjpa.org/content/upload/bjpa/BeyondtheCount2021.pdf

Publisher's Note Springer Nature remains neutral with regard to jurisdictional claims in published maps and institutional affiliations.

Helen K. Kim is Professor of Sociology at Whitman College. 